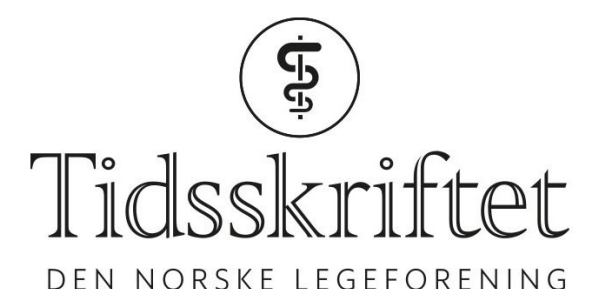

\title{
Rettelse: Assistert befruktning blant kvinner med epilepsi
}

RETTELSE

SABREEN ZAIDAN

KARL O. NAKKEN

KARI M. LILLESTØLEN

SILJE ALVESTAD

MORTEN I. LOSSIUS

Tidsskr Nor Legeforen 2020; 140: 51-3.

I Tidsskriftet nr. 1/2020 på s. 51 skal det stå: Hos kvinnene med epilepsi var 96 av 1510 barnefødsler $(6,4 \%)$ en følge av assistert befruktning, mens tilsvarende tall i den generelle befolkningen i samme periode var 28547 av $1052901(2,7 \%)(\mathrm{p}<0,001)$.

Vi beklager feilen, den er rettet på nett.

Publisert: 27. januar 2020. Tidsskr Nor Legeforen. DOI: 10.4045/tidsskr.20.0063

(C) Tidsskrift for Den norske legeforening 2020. Lastet ned fra tidsskriftet.no 